\title{
ATTRACTIVENESS OF POSSUM APPLE BAITS TO NATIVE BIRDS AND HONEY BEES
}

\author{
M.D. THOMAS ${ }^{1}$, F.W. MADDIGAN ${ }^{1}$ and L.A. SESSIONS ${ }^{2}$ \\ ${ }^{1}$ Pest Control Research, PO Box 7223, Christchurch, New Zealand \\ ${ }^{2}$ University of Canterbury, Private Bag 4800, Christchurch \\ Corresponding author: malcolm.thomas@pcr.co.nz
}

\begin{abstract}
This study investigated the potential risks of using 1080 apple bait for possum control on non-target species. Trials were conducted using captive native birds at Orana Park and honeybees (Apis mellifera) at Halswell to determine whether these species would feed on non-poisonous apple baits. Bird species were kaka (Nestor meridionalis), kea (Nestor notabilis), kakariki (Cyanoramphus sp.), silvereye (Zosterops lateralis), weka (Gallirallus australis) and kereru (Hemiphaga novaeseelandiae). Kaka, kea, kakariki and silvereye preferred to feed on apple bait over carrot bait, spending 74-100\% of their feeding time on the apple bait. Honeybees were not attracted to the apple bait. It is concluded that there could be a greater risk to native birds when apple baits are used for possum control compared to the risk associated with using carrot bait. Consequently it is recommended that aerial application of apple should not be undertaken and that apple baits should be used in bait stations only.

Keywords: 1080, sodium monofluoroacetate, possums, poisoning, vertebrate pest control.
\end{abstract}

\section{INTRODUCTION}

The brushtail possum (Trichosurus vulpecula) was first introduced into New Zealand from Australia in 1837. Today about 70 million inhabit more than $90 \%$ of the New Zealand mainland, and this species is considered one of the most damaging animal pests throughout most of the country. Numerous native plant species have declined because of possum browsing. Furthermore, because possums have strong preferences for certain plant species, they may alter the composition of native forests and even cause the collapse of forest canopy in places where preferred species are abundant. Possums can compete with native birds for food or den sites, and prey on the eggs and chicks of some species. Possums are also an economic burden to New Zealand because they cause damage to agricultural crops and commercial pine plantations, and they carry bovine tuberculosis (Tb), which poses a potential threat to New Zealand's beef, dairy and venison industries.

The possum control industry is continually seeking more cost-effective ways to control possums. Baits made from vegetables, such as carrot, are a common method for possum control (Morgan \& Hickling 2000), and provided carrot baits are prepared correctly the risk to native birds is low (Spurr 2000). Baits are also made from cut apple and are especially used in areas such as the Bay of Plenty where apple can be obtained cheaply. Both carrot and apple are surface coated with sodium monofluroroacetate (1080) which poisons the possums. Green dye is used to identify baits as being toxic, and to make them less attractive to birds (Cathness \& Williams 1971). In addition, cinnamon oil is added to carrot baits to provide a partial bird repellent (Spurr 1994; Hickling 1997) and to mask the taste of the 1080 to possums (Morgan 1990). Apple is coated with orange oil as a mask for 1080 (Morgan 1990). Cinnamon oil is unsuitable for apple since it rapidly turns apple baits brown, because of its high acidity, and reduces its palatability to possums. Orange oil has no recorded repellent properties to birds. 
In 1996, the Wellington Regional Council (WRC) began trials where they alternated 1080 bait types (apple, cereal, carrot and paste) in an attempt to overcome 1080 bait shyness (Morgan et al. 1996; O'Conner \& Matthews 1999). These trials indicated that 1080 apple baits are highly palatable to possums and can produce good possum kills (D. Meenken, unpubl. data).

Although apple baits may provide an effective option for possum control, the risks to non-target animals, such as native birds, and the risk of contamination of honey through honeybees (Apis mellifera) feeding on the baits have not been assessed. Research suggests that, despite some deaths to native birds, 1080 poisoning operations generally have no impact or indirectly a positive impact on populations of native birds (Spurr 2000). However, individual deaths of native birds should be avoided and are unacceptable for rarer species such as the kaka (Nestor meridionalis) and kakariki (Cyanoramphus sp.). Honey bees have also been known to be attracted to 1080 apple paste baits that contain a large percentage of cane sugar (Goodwin \& Ten Houten 1991). This can lead to death of bees and contamination of honey with 1080 . The purpose of this study was to assess the potential risks that apple baits could pose to native birds and contamination of honey.

\section{Birds}

\section{METHODS}

The time captive native birds spent feeding on non-toxic apple baits compared to the time the birds spent feeding on non-toxic carrot baits was recorded. Fresh apple and carrot were cut into 10-25 g pieces. Both baits types were coated with a green dye so that it had a colour range of 221-267 using the New Zealand Standard Specification 7702 (Eason \& Wickstrom 2001). The baits were also coated with $0.3 \%$ wt/wt of either cinnamon oil (for carrots) or orange oil (for apple). Approximately 10 non-toxic carrot baits and 10 non-toxic apple baits were presented simultaneously to captive native birds over a 3-day period in March 2001 at Orana Wildlife Park, Christchurch. The birds were weka (Gallirallus australis; $\mathrm{n}=2)$, kaka $(\mathrm{n}=1)$, kea (Nestor notabilis; $\mathrm{n}=4)$, kakariki $(\mathrm{n}=11)$, kereru (Hemiphaga novaeseelandiae; $\mathrm{n}=8)$ and silvereye (Zosterops lateralis; sample size was large but exact numbers were not counted as silvereyes were free to fly into and out of the cages). The normal diet fed to these birds was as follows:

$\begin{array}{ll}\text { Weka } & \text { meat mix including egg and bran plus day old chicks and mice } \\ \text { Kaka } & \text { fruit and vegetable mix including some carrot } \\ \text { Kea } & \text { apple and carrot } \\ \text { Kakariki } & \text { fruit and vegetable mix including some carrot } \\ \text { Kereru } & \text { fruit only } \\ \text { Silvereye } & \text { apple and carrot }\end{array}$

Birds were observed for at least 6 hours per day and the time (to the nearest minute) that individual birds spent feeding on the two bait types was recorded.

\section{Bees}

To assess the risk of honey bees feeding on apple baits and contaminating honey a trial was conducted on farmland near Christchurch in May 2001 using the methodology described in Morgan (1999). Two Petri dishes containing a cane sugar solution were placed $1 \mathrm{~m}$ from two active beehives to habituate them to feeding at the dishes. The number of bees feeding at the dishes was recorded every 5 min for $1 \mathrm{~h}$. The cane sugar solution was then replaced with apple bait and the number of bees feeding was again counted at $5 \mathrm{~min}$ intervals for $1 \mathrm{~h}$. This procedure was undertaken 3 times per day for 3 consecutive days, i.e. 36 readings per day for 3 days. The number of bees per 5 minute interval that fed on the cane sugar solution and apple bait was compared using a $t$ test to determine whether significant differences occurred. 


\section{RESULTS}

All of the birds except weka spent more time feeding on the apple bait than on the carrot bait. Kaka spent $74 \%$, kea $87 \%$, kakariki $96 \%$ and silvereye $100 \%$ of their bait feeding time on the apple baits (Table 1). Kereru did not feed on either the carrot or apple baits.

TABLE 1: Mean time per day, in minutes and as a percentage, that captive bird species spent feeding on apple and carrot possum baits over a 6 hour period for 3 days.

\begin{tabular}{lccrcrr}
\hline & & \multicolumn{2}{c}{ Apple } & & \multicolumn{2}{c}{ Carrot } \\
\cline { 3 - 4 } Species & $\mathrm{n}$ & Mean $(\mathrm{min})$ & $\%$ & & Mean $(\mathrm{min})$ & $\%$ \\
\hline Kaka & 1 & $11.3(7.8)^{1}$ & 74 & & $4.0(2.6)$ & 26 \\
Kea & 4 & $62.0(25.4)$ & 87 & & $9.3(2.8)$ & 13 \\
Kakariki & 11 & $7.6(1.2)$ & 96 & & $7.6(1.2)$ & 4 \\
Silvereye & unknown & $5.5(2.8)$ & 100 & & $10.0(3.5)$ & 50 \\
Weka & 2 & $10.0(2.3)$ & 50 & & 0 & 0 \\
Kereru & 8 & 0 & 0 & &
\end{tabular}

${ }^{1}$ Data in parentheses are the SEM.

For the honey bees, a mean of 10.1 bees were recorded per 5 minute count on the cane sugar solution ( $\mathrm{SEM}=1.9)$ and significantly less $(0.2$ per 5 minute count $)$ on the apple $(\mathrm{SEM}=0.04)(t=5.2 ; \mathrm{P}<0.0001 ; \mathrm{df}=214)$.

\section{DISCUSSION}

This study suggests that the use of apple baits for possum control could pose greater risks to native birds than baiting with carrot. Most of the captive birds in this study spent more time feeding on the apple bait than on the carrot bait. However, this study used captive birds, and birds in the wild could behave differently. Spurr (1993) noted that possum baits may be less acceptable to wild birds that are not habituated to an artificial diet including carrot and apple. But on the other hand, these baits may be more acceptable to wild birds if they are faced with food shortages. Field trials in a range of habitat types would build on the information gained in this study.

Few bees fed on the apple bait, despite being attracted to it by prior feeding with cane sugar. There have been instances of honey bees being killed after feeding on 1080 paste baits containing cane sugar when nectar is in short supply (Goodwin \& Ten Houten 1991). However, the very low sugar content of apple baits and the results from this trial suggest that bees are unlikely to be killed and the risk of 1080 contamination of honey is negligible.

Until more comprehensive field-based studies that observe feeding behaviour of wild birds on possum baits are undertaken, it is recommended that caution is used with apple baits. Consequently it is suggested that apple baits be used only in bait stations. Bait stations are designed specifically to feed possums and they help preclude non-target species such as birds. In addition, less bait is required in bait stations compared to other methods, such as aerial application, and unused bait can be more easily removed from the field (Thomas 1994). Aerial application of apple bait is not recommended. Apple is softer than carrot and the mechanical sowing buckets used for aerial bait application are likely to fragment the apple. This could further increase the risk to birds as small bait fragments have been implicated in increased bird deaths (Spurr 1994).

\section{ACKNOWLEDGEMENTS}

We would like to thank the Animal Health Board for funding this study. Jennifer Brown (University of Canterbury) gave helpful advice on the project design and provided editorial assistance. We would also like to thank Ian Adams and staff of Orana Park for kindly allowing us to undertake the native bird trials. 


\section{REFERENCES}

Caithness, T.A.; Williams, G.R. 1971: Protecting birds from poisoned baits. N. Z. J. Agric. 122(6): 38-43.

Eason, C.T.; Wickstrom, M. 2001: Vertebrate pesticide toxicology manual (poisons). Department of Conservation Technical Series 23. 122 p.

Goodwin, R.M.; Ten Houten, A. 1991: Poisoning of honey bees (Apis mellifera) by sodium fluoroacetate (1080) in baits. N.Z. J. Zool. 18: 45-51.

Hickling, G.J. 1997: Effect of green dye and cinnamon oil on consumption of cereal pest baits by captive North Island kaka (Nestor meridionalis). N.Z. J. Zool. 24: 239-242.

Morgan, D.R. 1990: Behavioural response of brushtail possums Trichosurus vulpecula to baits used in pest control. Wildlife Res. 17: 601-613.

Morgan, D.R.; Morris, G.; Hickling, G.J. 1996: Induced 1080 bait-shyness in captive brushtail possums and implications for management. Wildlife Res. 23: 207-211.

Morgan, D.R. 1999: Risks to non-target species from use of a gel bait for possum control. N.Z. J. Ecol. 23(2): 281-287.

Morgan, D.R.; Hickling, G.J. 2000: Techniques used for poisoning possums. In: Montague, T. L. ed. The brushtail possum : the Biology, Impact and Management of An Introduced Marsupial. Manaaki Whenua Press, Lincoln, New Zealand. Pp. 143-153.

O'Connor, C.E.; Matthews, L.R. 1999: 1080-induced bait aversion in wild possums: Influence of bait characteristics and prevalence. Wildlife Res. 26: 375-381.

Spurr, E.B. 1993: Feeding by captive rare birds on baits used in poisoning operations for control of brushtail possums. N.Z. J. Ecol. 17(1):13-18.

Spurr, E.B. 1994: Review of the impacts on non-target species of sodium monofluoroacetate (1080) in baits used for brushtail possum control in New Zealand. In: Seawight, A.A.; Eason, C.T. ed. Proceedings of the science workshop on 1080. Royal Soc. Misc. Series 28: 124-133.

Spurr, E.B. 2000: Impacts of possum control on non-target species. In: Montague, T.L. ed. The brushtail possum : the Biology, Impact and Management of An Introduced Marsupial. Manaaki Whenua Press, Lincoln, New Zealand. Pp. 175-186.

Thomas, M.D. 1994: Possum control in native forests using sodium monofluoroacetate (1080) in bait stations. Proc. 47th N.Z. Plant Prot. Conf.: 107-111. 